\title{
Optimal technical management of stump closure following distal pancreatectomy: a retrospective review of 215 cases.
}

\author{
Lisa J. Harris \\ Thomas Jefferson University \\ Hamid Abdollahi \\ Thomas Jefferson University \\ Timothy Newhook \\ Thomas Jefferson University \\ Patricia K. Sauter \\ Thomas Jefferson University \\ Alhert friisarawfardfitional works at: https://jdc.jefferson.edu/surgeryfp \\ Thomas Jefferson University \\ Part of the Surgery Commons

\section{Let us know how access to this document benefits you}

\section{Recommended Citation}

Harris, Lisa J.; Abdollahi, Hamid; Newhook, Timothy; Sauter, Patricia K.; Crawford, Albert G.;

Chojnacki, Karen A.; Rosato, Ernest L.; Kennedy, Eugene P.; Yeo, Charles J.; and Berger, Adam C., "Optimal technical management of stump closure following distal pancreatectomy: a retrospective review of 215 cases." (2010). Department of Surgery Faculty Papers. Paper 31. https://jdc.jefferson.edu/surgeryfp/31

This Article is brought to you for free and open access by the Jefferson Digital Commons. The Jefferson Digital Commons is a service of Thomas Jefferson University's Center for Teaching and Learning (CTL). The Commons is a showcase for Jefferson books and journals, peer-reviewed scholarly publications, unique historical collections from the University archives, and teaching tools. The Jefferson Digital Commons allows researchers and interested readers anywhere in the world to learn about and keep up to date with Jefferson scholarship. This article has been accepted for inclusion in Department of Surgery Faculty Papers by an authorized administrator of the Jefferson Digital Commons. For more information, please contact: JeffersonDigitalCommons@jefferson.edu. 


\section{Authors}

Lisa J. Harris, Hamid Abdollahi, Timothy Newhook, Patricia K. Sauter, Albert G. Crawford, Karen A. Chojnacki, Ernest L. Rosato, Eugene P. Kennedy, Charles J. Yeo, and Adam C. Berger 


\title{
Submitted to:
}

Journal of Gastrointestinal Surgery

October 2009

\author{
Later published as:
}

"Optimal Technical Management of Stump Closure Following Distal Pancreatectomy: A Retrospective Review of 215 Cases"

\author{
Volume 14, Issue 6, 2010, Pages 998-1005 \\ DOI: $10.1007 / \mathrm{s} 11605-010-1185-\mathrm{Z}$
}

Revised Manuscript: December 2009

Lisa J. Harris M.D., Hamid Abdollahi M.D., Timothy Newhook, Patricia K. Sauter A.C.N.P, Albert G. Crawford PhD MBA, Karen A. Chojnacki M.D., Ernest L. Rosato M.D., FACS, Eugene P. Kennedy M.D.,FACS, Charles J. Yeo M.D.,FACS, Adam C. Berger M.D., FACS.

Department of Surgery, Jefferson Pancreas and Related Cancers Center,

Thomas Jefferson University, Philadelphia, Pennsylvania

Correspondence to: 
Adam C. Berger, MD; Associate Professor, Department of Surgery,Thomas Jefferson University; 1100 Walnut Street, M.O.B. Suite 500; Philadelphia, PA 19107; Phone: 215-955-1622,

Fax: 215-923-8222

Email: adam.berger@jefferson.edu

Poster presentation at the $50^{\text {th }}$ Annual Meeting of the Society of Surgery of the Alimentary Tract (Chicago, IL, June, 2009).

Running Title: Fistula after distal pancreatectomy

Key Words: distal pancreatectomy; pancreatic fistula; complications 


\section{ABSTRACT}

Background: Pancreatic fistula (PF) is a major source of morbidity following distal pancreatectomy (DP). Our aim was to identify risk factors related to PF following DP and to determine the impact of technique of transection and stump closure.

Methods: We performed a retrospective review of 215 consecutive patients who underwent DP. Perioperative and postoperative data were collected and analyzed with attention to PF as defined by the International Study Group of Pancreatic Fistula (ISGPF).

Results: PF developed in 36 patients (16.7\%); fistulas were classified as Grade A (44.4\%), B $(44.4 \%)$, or $\mathrm{C}(11.1 \%)$. The pancreas was transected with stapler $(\mathrm{n}=139)$, cautery $(\mathrm{n}=70)$ and scalpel $(n=3)$. PF developed in $19.8 \%$ of remnants which were stapled/oversewn and $27.7 \%$ that were stapled alone $(\mathrm{p}=0.4)$. Of the 69 pancreatic remnants transected with cautery and oversewn, a fistula developed in $4.3 \%$ ( $\mathrm{p}=0.004$ compared to stapled/oversewn; $\mathrm{p}=0.006$ compared to stapled/not sewn). The median length of post-operative hospital stay was significantly increased in patients who developed PF (10 vs. 6 days, $\mathrm{p}=0.002$ )

Conclusion: The method of transection and management of the pancreatic remnant plays a critical role in the formation of PF following DP. This series suggests that transection using electrocautery followed by oversewing of the pancreatic remnant has the lowest risk of PF. 


\section{INTRODUCTION}

Distal pancreatectomy (DP) is the procedure of choice for benign or malignant lesions in the pancreatic body or tail. The typical procedure consists of resection of the pancreatic parenchyma at a variable point to the left of the superior mesenteric vein-portal vein axis, and may include concomitant removal of the spleen. For decades, DP had been associated with high morbidity and low but measurable mortality. In recent years, the mortality rate after DP has been reduced to less than five percent in high volume centers ${ }^{1-5}$, however morbidity rates remain high ranging from $10-47 \%^{3,6-8}$. Pancreatic fistula is the most frequently reported complication and the primary cause of post-operative morbidity following $\mathrm{DP}^{6-10}$. Development of pancreatic fistula often leads to further complications such as intra-abdominal abscess, sepsis, hemorrhage, delayed gastric emptying, and occasionally malabsorption. These additional complications have important implications for the healthcare system, often with additional procedures, increased length of hospital stay and increased cost ${ }^{9-11}$.

While it is clear that pancreatic fistula remains a problem following DP, the risk factors for development of fistula are not well defined. Obesity, patient age, trauma, malignancy, duct obstruction and texture of the pancreatic parenchyma have all been implicated as potential risk factors $^{9,12}$. However, surgical technique is also considered an important risk factor for the development of pancreatic fistula ${ }^{9}$. A wide variety of surgical techniques for parenchymal transection and closure of the pancreatic remnant have been described in an effort to reduce the occurrence of fistula. These techniques include stapled closures, sutured closures, combined stapled and sutured closures, ultrasonic dissection, sealing with fibrin glue, application of mesh, seromuscular flaps, pancreaticoenteric anastomosis and ligation of the main pancreatic duct at the transection line ${ }^{3,6-9,11-21}$. Currently, there is no consensus as to the optimal surgical technique 
for pancreatic transection and stump closure during distal pancreatectomy. The purpose of this study is to determine the impact of the type of pancreatic transection and closure of the pancreatic remnant on the formation of pancreatic fistula. 


\section{MATERIAL AND METHODS}

Our Institutional Review Board approved this retrospective review of all patients who underwent distal pancreatectomy at Thomas Jefferson University Hospital from January 1996 through July 2008. Patients who underwent distal pancreatectomy were identified using electronic search of a surgical database. The indications for distal pancreatectomy included primary pancreatic processes, non-pancreatic malignancies and trauma. No patients were excluded from the study. Octreotide was rarely used in the preoperative, prophylactic setting, but was often used in patients with documented pancreatic fistulae.

Patient data including demographics, comorbidities, additional procedures, method of pancreatic transection, management of the pancreatic remnant, operative time, blood loss, pathology, and post-operative complications were collected using hospital electronic record and chart review. These data were compiled and further analyzed. The primary endpoint was pancreatic fistula. Pancreatic fistula was defined using the International Study Group on Pancreatic Fistula (ISGPF) definition: drainage of any measurable volume after post-operative day 3 , with an amylase content of greater than three times the normal serum value ${ }^{22}$. Pancreatic fistulas were retrospectively graded according to the ISGPF grading system ${ }^{22}$. Secondary endpoints were all complications.

\section{Statistical Analysis}

Continuous variables (such as length of post-operative hospital stay) were compared using a two-sided Student's t-test. Qualitative variables (such as pancreatic fistula rates) were compared using Fisher's exact test. Bivariate crosstabulations, with Chi-square statistics, to assess bivariate associations between selected risk factors and the occurrence of fistulas were performed. A multivariate logistic regression analysis which modeled the occurrence of fistulas 
as a function of all risk factors with significant bivariate associations and also selected other variables (i.e., age group, sex, body mass index, and estimated blood loss) to assess and control for confounding was performed. A p-value less than 0.05 was considered significant. SAS Release 9.2 statistical software (SAS Institute, Inc., Cary, NC) was used for all analyses. 


\section{RESULTS}

From January 1996 to July 2008, 215 patients underwent distal pancreatectomy. There were more females $(n=125 ; 58 \%)$ than males $(n=90 ; 42 \%)$. The mean age of patients was 58.8 years (range, 18-87 years). Indications for distal pancreatectomy are listed in Table 1. More patients were operated on for benign lesions (61\%) than for malignancies (39\%). The most frequent benign lesions were cystadenomas (12.6\%), intra-ductal papillary mucinous neoplasms (IPMN; 9.8\%), and neuroendocrine tumors (9.8\%). Eight patients (3.7\%) underwent distal pancreatectomy for pancreatic trauma. Of the malignant lesions, pancreatic ductal adenocarcinoma (19\%) and neuroendocrine tumors (9.8\%) were the most frequent indications.

Open distal pancreatectomy with splenectomy was performed in $84 \%$ of patients (Table 2). Open distal pancreatectomy with splenic preservation was performed in 9\%. Laparoscopic resection was attempted in 16 patients $(7.4 \%)$ and completed in 13 patients $(6 \%)$. Additional organs, excluding the spleen, were resected in 108 patients $(50 \%)$; the majority of these were incidental cholecystectomies (Table 3). The mean operative time was 274 minutes (range 83$665)$ and the average blood loss was 621 milliliters (range 0-5400). The pancreas was transected using a stapler in 139 patients, electrocautery in 70 patients, and scalpel in 3 patients (unknown in 3 patients) (Figure 1). Of the 139 patients who were transected with stapler, the pancreatic remnant was oversewn in 91 patients, not oversewn in 47 patients, and sealed with tissue glue in one patient. Of the 70 patients who were transected with electrocautery, the pancreatic remnant was oversewn in 69 patients and not oversewn in one patient. For the 3 patients who were transected with scalpel, the remnant was oversewn in one patient, not oversewn in one patient, and pancreatico-jejunostomy was performed in one patient. 
Pancreatic fistula was the most common complication, occurring in 36 patients (16.7\%).

Pancreatic fistula occurred in 50\% of patients undergoing laparoscopic spleen preserving distal pancreatectomy, $\mathbf{4 4 . 4 \%}$ of patients undergoing laparoscopic distal pancreatectomy and splenectomy, $15.6 \%$ of patients undergoing open distal pancreatectomy and splenectomy, and $10.0 \%$ of patients undergoing open spleen preserving distal pancreatectomy. The characteristics of patients who developed a pancreatic fistula are described in Table 4. Fistulas were classified as Grade A in 16 patients (44.4\%), Grade B in 16 patients (44.4\%), and Grade C in 4 patients (11.1\%). Pancreatic fistula developed in $27.7 \%$ of patients that were stapled and not oversewn, $19.8 \%$ of patients where the remnants were stapled and oversewn, and only in $4.3 \%$ of remnants that were divided by cautery and oversewn (Figure 1). The fistula rate for remnants that were cauterized and oversewn was significantly lower as compared to the leak rate in both stapled and oversewn $(\mathrm{p}=0.004)$ and stapled and not oversewn $(\mathrm{p}=0.0006)$. There was no difference in the incidence of pancreatic fistula between patients who had additional organs (excluding spleen) resected compared to those where no additional organs were resected (13\% vs. $20.6 \% ; \mathbf{p}=\mathbf{0 . 1 5})$. Of the 13 laparoscopic cases (all stapled and none oversewn), six (46.2\%) developed pancreatic fistula.

The median length of post-operative hospital stay was significantly increased in patients who developed pancreatic fistula, as compared to those who did not develop a fistula (10 days versus 6 days; $\mathrm{p}=0.002$ ) (Table 4). Pancreatic fistula was treated with maintenance of JP drainage alone in $41.7 \%$ of patients and maintenance of JP drainage plus octreotide in $30.6 \%$ of patients. Percutaneous drain placement by interventional radiology was required in $22.2 \%$ of fistulas. Three patients who developed fistula required re-operation; all three had Grade C fistulas. 
Fifty-five patients (25.6\%) developed at least one post-operative complication (Table 5). There were two peri-operative deaths $(0.9 \%)$. One was a patient with malignant pheochromocytoma adherent to the pancreas and spleen, who developed post-operative sepsis and multi-system organ failure (death on post-operative day \#48). The other mortality was a patient with metastatic melanoma who expired from unexpected cardiac arrest in the postoperative period (death on post-operative day \# 21).

We also examined fistula rates based on surgical volume at the entire institution. As one can see from Figure 2, the volume of pancreatic surgery increased by several-fold beginning in 2006. Prior to this point, there were a total of 93 distal pancreatectomies, while starting in 2006, there were a total of 120 distal pancreatic resections. When calculating leak rates pre- and post-2006, there is a significant decrease in leak rates (26\% vS. $10 \%, p=0.003)$.

Bivariate analyses showed that pancreatic transection using a stapler, not oversewing the pancreatic remnant, and low surgeon volume (fewer than 20 total cases performed) were all significantly associated with the development of pancreatic fistula (Table 6). While the bivariate analyses show significant differences in the likelihood of a pancreatic fistula, as noted, none of these differences remained significant in the multivariate logistic regression analysis (Table 7), although the method of pancreatic transaction was borderline significant $(\mathrm{p}=0.058)$ with a hazard ratio of 3.2 . 


\section{DISCUSSION}

In the present study, we analyzed the morbidity and mortality associated with DP, with particular attention to pancreatic fistula and surgical technique. For the 215 patients in this series, we report a mortality rate of $0.9 \%$ and a morbidity rate of $25.6 \%$. Pancreatic fistula was the most frequent complication, occurring in $16.7 \%$ of patients. We found a significantly lower fistula rate in pancreatic remnants that were transected by cautery and oversewn (4.3\%), as compared to remnants that were stapled and oversewn $(19.8 \% ; \mathrm{p}=0.004)$ or stapled and not oversewn $(27.7 \%$; $=0.0006)$. In our relatively small laparoscopic group, $46.2 \%$ developed pancreatic fistula. Median length of stay was significantly increased in patients who developed pancreatic fistula compared to those who did not (10 days versus 6 days; $p=0.002)$.

Our data support the claim that DP can be performed with low mortality ${ }^{1-5}$, however, morbidity remains high largely due to pancreatic fistula. Our pancreatic fistula rate falls within the range of $3-26 \%$ reported in the literature ${ }^{3,6-8}$. This wide variability of fistula rates is likely due to discrepancy in the diagnostic criteria used to define pancreatic fistula across the various studies. A review by Bassi et al identified more than 25 definitions of pancreatic fistula that vary based on the daily amount of drain output, amylase level of the fluid and duration of drainage ${ }^{23}$. In this study, pancreatic leaks were defined and classified according to the standard definitions outlined by the ISGPF. ${ }^{22}$ Pancreatic fistula was defined as a drain output of any measurable volume of fluid on or after post-operative day three with an amylase content greater than three times the serum amylase content. Grade A fistulas, or "transient fistulas", have little clinical impact. Grade B fistulas require a change in management, usually have persistent drainage after three weeks and may be associated with signs of infections. Grade C fistulas are associated with a major change in clinical pathway and patient stability may be borderline. The ISGPF 
definition has resulted in an internationally accepted standard definition of pancreatic fistula that allows for better comparisons between fistula rates from different institutions. Using the ISGPF definition, our pancreatic fistula rate of $16.7 \%$ falls in the middle of the range of reported rates in the literature. Given the fact that the ISGPF definition was not published until 2005, many leaks were identified and graded in a retrospective fashion by reviewing inpatient medical records.

Management of pancreatic fistula following DP has not been standardized. The majority of the pancreatic fistulas that occurred in our series were either Grade A or Grade B. All of these were managed conservatively. Intra-operatively placed drains were maintained and additional percutaneous drains were placed when necessary for undrained collections. Octreotide was administered to patients at the discretion of the surgeon. Patients were additionally supported with parenteral nutrition when indicated. Most patients had a delay in hospital discharge as a result of their fistula. With conservative management, all Grade A and B fistulas closed spontaneously. Four Grade $\mathrm{C}$ fistulas occurred in our study. Three of these required reoperation for either hemorrhage or abdominal sepsis. Mortality occurred in two patients with Grade C fistulas; both of these patients had malignant tumors with metastatic disease. The increased utilization of healthcare resources and potential severity of disease associated with pancreatic fistula illustrates the need for effective methods to reduce their incidence.

The optimal surgical technique for both pancreatic transection and closure of the pancreatic remnant remains a debate. A multitude of surgical techniques and instruments have been proposed for reducing the occurrence of pancreatic fistula. A partial list of techniques includes hand-sutured closure, stapled closure, sutured plus stapled closure, sealing with fibrin glue, application of mesh, seromuscular flaps, ultrasonic dissection, bipolar scissors, pancreaticoenteric anastomosis and ligation of the main pancreatic duct ${ }^{3,6-9,11-21}$. The most 
frequently used techniques are the suture and stapler closures of the pancreatic remnant. Kleeff et al have observed a significantly increased risk of pancreatic fistula with stapled closure ${ }^{9}$. In contrast, other investigators have reported increased pancreatic fistula rates with sutured closure of the pancreatic remnant ${ }^{3,14,15,24}$. Many have concluded that the method of stump closure has no impact on the incidence of pancreatic fistula ${ }^{12,13,21,25,26}$.

In our study, the surgical technique most commonly involved transection of the pancreatic parenchyma with a stapler or electrocautery. The pancreatic remnant was then either oversewn or not oversewn at the discretion of the attending surgeon. We found a significantly lower fistula rate in pancreatic remnants that were cauterized and oversewn (4.3\%), as compared to remnants that were stapled and oversewn $(19.8 \% ; \mathrm{p}=0.004)$ or stapled and not oversewn (27.7\%; $\mathrm{p}=0.0006)$. Bivariate analysis confirmed the importance of method of transaction $(\mathrm{p}=0.012)$, type of remnant closure/sealing $(\mathrm{p}=0.012)$, and surgeon volume $(\mathrm{p}<0.001)$ for pancreatic fistula after distal pancreatectomy. Multivariate analysis failed to demonstrate one single independent factor, although the method of pancreatic transection showed a nearly significant increase in risk of fistula $(\mathrm{p}=0.058$, hazard ratio $=3.2)$ with the use of non-stapled transection. It is likely that if there were more patients in our study, that this factor would have reached statistical significance.

Interestingly, surgeon volume was a significant factor in the determination of pancreatic fistula. We used a cutoff of $<20$ procedures during the period of this study. This left us with groups that were relatively equal in size. There were a total of 24 surgeons who performed distal pancratectomies in this series, with a volume range of one to 67 . The median number of cases performed was 2.5 , and there were three surgeons who performed more than 20 procedures with a leak rate of $10 \%$ in the high volume group, as compared to $28 \%$ for the lower volume surgeons. 
This factor was not, however, significant on multivariate analysis. Surgeon volume has not been thoroughly examined as a specific risk factor for pancreatic fistula after pancreatic resection, and in fact, ours is the first one that we could find that addressed its potential importance for leaks after distal pancreatectomy. Another fact that we found to be significant was institutional volume. Starting at the beginning of 2006 , there was a dramatic increase in the number of pancreatic resections performed. In 2006, 2007, and half of 2008, there were a total of 120 distal pancreatectomies a year (mean=40 per year), while in the prior years of the study, there were 93 distal resections (mean=9.5). As one would expect, the increased institutional volume lead to a significant decrease in the number of pancreatic fistulae (26\% vs. $10 \%$, $\mathbf{p}=\mathbf{0 . 0 0 3})$.

Several authors state that the texture of the pancreatic parenchyma is an important risk factor associated with the development of post-operative pancreatic fistula. ${ }^{3,12,13}$ Fibrotic pancreatic tissue is believed to be less likely to leak as compared to soft pancreatic parenchymal tissue, as long as the continuity of the main pancreatic duct is not compromised. Due to the retrospective nature of our study, we were unable to include pancreatic texture as a variable in our analysis as we found that it was not consistently reported in the operative reports and medical records that were reviewed.

The administration of prophylactic octreotide to reduce the incidence of postoperative pancreatic fistula remains controversial. Several studies have shown that prophylactic octreotide reduces the rate of pancreatic fistula following elective pancreatic resection. $^{27-30}$ In contrast, other authors have shown no benefit to the use of prophylactic octreotide. $^{31,32}$ Prophylactic octreotide was not included as a variable in our study. The 
retrospective nature of our study precluded its use as a variable for analysis, as we found that it was not consistently reported in the reviewed medical records.

Laparoscopic surgery has quickly been adopted as the standard for a variety of solid organ resections. In the surgical treatment of pancreatic disease, laparoscopic resections are becoming increasingly popular. To date, most reports of laparoscopic distal pancreatectomy are small series from single institutions. ${ }^{33-38}$ The occurrence of pancreatic fistula following laparoscopic distal pancreatectomy in these studies has been reported as ranging from 13-50\%. ${ }^{33-}$

${ }^{38}$ A large, multi-center retrospective reviewe comparing laparoscopic distal pancreatectomy with open distal pancreatectomy reported shorter length of hospital stay with laparoscopic distal pancreatectomy and no significant differences in major complication rate or pancreatic fistula rate when compared to open distal pancreatectomy. ${ }^{39}$ In our series, laparoscopic distal pancreatectomy was attempted in 16 patients and completed in 13 patients. Pancreatic fistula occurred in $6(42.6 \%)$ of these 13 patients. This fistula rate is at the higher end of the reported ranges in the literature. We expect that as this technique becomes more widely used and newer techniques are developed, the incidence of pancreatic fistula will decrease.

Our institution has recently opened a randomized, prospective clinical trial evaluating the method of pancreatic stump closure following distal pancreatectomy (NCT00889213). In this trial, patients are stratified by pancreatic texture and randomized to one of two methods of closure-standard closure (investigator's choice of stapler, cautery or sharp transaction with suture closure at surgeon's discretion) or experimental closure which adds an autologous falciform patch and the placement of fibrin glue (Vitagel) between the parenchyma and the patch. This trial began accruing patients in August 2008 and has an accrual goal of 190 patients. 
We hope that this trial will help to resolve the controversy around management of the pancreatic stump after distal pancreatectomy.

In summary, pancreatic fistula remains a significant cause of the morbidity associated with distal pancreatectomy. The method of transection of the pancreatic parenchyma and management of the pancreatic remnant appear to be related to the formation of pancreatic fistula. This series suggests that transection using electrocautery followed by oversewing of the pancreatic remnant minimizes the formation of pancreatic fistula. Additional prospective, randomized studies are needed in order to determine the optimal surgical technique for parenchymal transection and remnant closure during distal pancreatectomy to minimize the occurrence of post-operative pancreatic fistula. 


\section{REFERENCES}

1. Neoptolemos JP, Russell RC, Bramhall S, et al. Low mortality following resection for pancreatic and periampullary tumours in 1026 patients: UK survey of specialist pancreatic units. UK Pancreatic Cancer Group. Br J Surg. 1997;84:1370-1376

2. Buchler MW, Wagner M, Schmied BM, et al. Changes in morbidity after pancreatic resection: toward the end of completion pancreatectomy. Arch Surg 2003;138:1310-1314.

3. Fahy BN, Frey CF, Ho HS, et al. Morbidity, mortality, and technical factors of distal pancreatectomy. Am J Surg 2002;183:237-241.

4. Grobmeyer SR, Pieracci FM, Allen PJ, et al. Defining morbidity after pancreaticoduodenectomy: use of a prospective complication grading system. J Am Coll Surg 2007;204:356-364

5. vanHeek NT, Kuhlmann KF, Scholten RJ, et al. Hospital volume and mortality after pancreatic resection: a systematic review and an evaluation of intervention in the Netherlands. Ann Surg 2005;242:781-788

6. Lillemoe KD, Kaushal S, Cameron JL, et al. Distal pancreatectomy: indications and outcomes in 235 patients. Ann Surg 1999;229:693-700.

7. Fabre JM, Houry S, Manderscheid JC, et al. Surgery for left-sided pancreatic cancer. Br J Surg 1996;83:1065-1070.

8. Bilimoria MM, Cormier JN, Mun Y, et al. Pancreatic leak after pancreatectomy is reduced following main pancreatic duct ligation. Br J Surg 2003;90:190-196.

9. Kleeff J, Diener MK, Z' graggen K, et al. Distal pancreatectomy: risk factors for surgical failure in 302 consecutive cases. Ann Surg 2007;245:573-582 
10. Balcom JH IV, Rattner DW, Warshaw Al, et al. Ten-year experience with 733 pancreatic resections: changing indications, older patients and decreasing length of hospitalization. Arch Surg 2001;136:391-398

11. Rodriguez JR, Germes SS, Pandharipande PV, et al. Implications and cost of pancreatic leak following distal pancreatic resection. Arch Surg 2006;141:361-365.

12. Ridolfini MP, Alferi S, Gourgiotis S, et al. Risk factors associated with pancreatic fistula after distal pancreatectomy, which technique of pancreatic stump closure is more beneficial? World J Gastroenterol 2007;13:5096-5100

13. Sheehan MK, Beck K, Creech S, et al. Distal pancreatectomy: does the method of closure influence fistula formation? Am Surg 2002;68:264-267.

14. Bassi C, Butturini G, Falconi M, et al. Prospective randomized pilot study of management of the pancreatic stump following distal resection. HPB 1999;1:203-207

15. Takeuchi K, Tsuzuki T, Ando T, et al. Distal pancreatectomy: is staple closure beneficial? Aust N Z J Surg 2003;73:922-925

16. Suzuki Y, Fujino Y, Tanioka Y, et al. Randomized clinical trial of ultrasonic dissector or conventional division in distal pancreatectomy for non-fibrotic pancreas. Br J Surg 1999;86:608611.

17. Ohwada S, Ogawa T, Tanahashi Y, et al. Fibrin glue sandwich prevents pancreatic fistula following distal pancreatectomy. World J Surg 1998;22:494-498

18. Kuroki T, Tajima Y, Kanematsu T. Surgical management for the prevention of pancreatic fistula following distal pancreatectomy. J Hepatobiliary Pancreat Surg 2005;12:283-285.

19. Kawai M, Tani M, Yamaue H. Transection using bipolar scissors reduced pancreatic fistula after distal pancreatectomy. J Hepatobiliary Pancreat Surg 2008;15:366-372. 
20. Jimez R, Mavanur A, Macaulay W. Staple line reinforcement reduced postoperative pancreatic stump leak after distal pancreatectomy. J Gastroint Surg 2007;11:345-349.

21. Ferrone C, Warshaw A, Rattner D, et al. Pancreatic fistula rates after 462 distal pancreatectomies: staplers do not decrease fistula rates. J Gastrointest Surg 2008;12:1691-1698.

22. Bassi C, Dervenis C, Butturini G, et al. Postoperative pancreatic fistula: an international study group (ISGPF) definition. Surgery 2005;138:8-13

23. Bassi C, Butturini G, Molinari E, et al. Pancreatic fistula rate after pancreatic resection: the importance of definitions. Dig Surg 2004;21:54-59.

24. Goh B, Ten Y, Chung YA, et al. Critical appraisal of 232 consecutive distal pancreatectomies with emphasis on risk factors, outcome, and management of the postoperative pancreatic fistula. Arch Surg 2008;143:956-965.

25. Bilimoria MM, Evans DB, Lee JE, et al. Pancreatic closure after distal pancreatectomy: relationship to postoperative pancreatic fistula. Presented at the $53^{\text {rd }}$ Annual Cancer Symposium of the Society of Surgical Oncology, New Orleans, LA, March 16-19, 2000.

26. Pannegeon V, Pessaux P, Sauvanet A, et al. Pancreatic fistula after distal pancreatectomy: predictive risk factors and value of conservative treatment. Arch Surg 2006;141:1071-1076.

27. Büchler M, Friess H, Klempa I, et al. Role of octreotide in the prevention of postoperative complications following pancreatic resection. Am J Surg 1992; 163: 125-131. 28. Pederzoli P, Bassi C, Falconi M, et al. Efficacy of octreotide in the prevention of complications of elective pancreatic surgery. Br J Surg 1994; 81: 265-269.

29. Montorsi M, Zago M, Mosca $F$, et al. Efficacy of octreotide in the prevention of pancreatic fistula after elective pancreatic resections: a prospective, controlled, randomized clinical trial. Surgery 1995; 117: $26-31$. 
30. Friess H, Beger HG, Sulkowski U, et al. Randomized controlled multicentre study of the prevention of complications by octreotide in patients undergoing surgery for chronic pancreatitis. Br J Surg 1995; 82: 1270-1273.

31. Lowy AM, Lee JE, Pisters PWT, et al. Prospective randomized trial of octreotide to prevent pancreatic fistula after pancreaticoduodenectomy for malignant disease. Ann Surg 1997; 226: 632-641.

32. Yeo CJ, Cameron JL, Lillemoe KD, et al. Does prophylactic octreotide decrease the rates of pancreatic fistula and other complications after pancreaticoduodenectomy?: Results of a prospective, randomized placebo-controlled trial. Ann Surg 2000;232: 419429.

33. Tang CN, Tsui KK, Ha JP, et al. Laparoscopic distal pancreatectomy: a comparative study. Hepatogastroenterology 2007;54:265-271.

34. Pierce RA, Spitler JA, Hawkins WG, et al. Outcomes analysis of laparoscopic resection of pancreatic neoplasms. Surg Endosc 2007;21:579-586.

35. Pryor A, Means JR, Pappas TN. Laparoscopic distal pancreatectomy with splenic preservation. Surg Endosc 2007;21:2326-2330.

36. Abu Hilal M, Jain G, Kasasbeh F, et al. Laparoscopic distal pancreatectomy: critical analysis of preliminary experience from a tertiary referral centre. Surg Endosc 2009;DOI 10.1007/s00464-009-0499-y.

37. Patterson EJ, Gagner M, Salky B, et al. Laparoscopic pancreatic resection: single-institution experience of 19 patients. J Am Coll Surg 2001;193:281-287.

38. Velanovich V. Case-control comparison of laparoscopic versus open distal pancreatectomy. J Gastrointest Surg 2006;10:95-98. 
39. Kooby DA, Gillespie T, Bentrem D, et al. Left-sided pancreatectomy: a multicenter comparison of laparoscopic and open approaches. Ann Surg 2008;248:438-446. 
Table 1. Indications for distal pancreatectomy.

\section{Indications for Distal Pancreatectomy ( $n=215$ patients)}

Benign
Cystadenoma (serous and mucinous)
IPMN
Neuroendocrine
Solid Pseudopapillary Neoplasm
Pseudocyst
Trauma
Chronic Pancreatitis
Cysts
Microcystic Adenoma
Abscess
Pancreatic Intraepithelial Neoplasia
Inflammatory Myofibroblastic Tumor
Miscellaneous
Total Benign
Malignant
Ductal Adenocarcinoma
Neuroendocrine
Metastatic Tumors
Mucinous Cystadenocarcinoma
Gastric Cancer
Adenosquamous Carcinoma
Anaplastic Carcinoma
Acinar Cell Carcinoma
Lymphoma
Liposarcoma
Total Malignant

\# (\%) of

patients

$27(12.6)$

$21(9.8)$

$21(9.8)$

$13(6.0)$

8 (3.7)

8 (3.7)

$\begin{array}{ll}7 & (3.3) \\ & 7\end{array}$

$\begin{array}{ll}7 & (3.3) \\ & (2.8)\end{array}$

$6 \quad(2.8)$

$2(0.9)$

$2(0.9)$

$1 \quad(0.5)$

$9 \quad(4.2)$

$132(61 \%)$

$41(19.0)$

$21(9.8)$

8 (3.7)

3 (1.4)

3 (1.4)

$2(0.9)$

$2(0.9)$

$1(0.5)$

1 (0.5)

$1 \quad(0.5)$

$83(39 \%)$ 
Table 2. Demographics and clinical characteristics.

\begin{tabular}{|c|c|}
\hline \multicolumn{2}{|c|}{$\begin{array}{c}\text { Demographic and Clinical Characteristics } \\
\text { (Total=215 patients) }\end{array}$} \\
\hline Mean Age in years (range) & $58.8(18-87)$ \\
\hline Female & $125(58 \%)$ \\
\hline Male & $90(42 \%)$ \\
\hline \multicolumn{2}{|l|}{ Race } \\
\hline Caucasian & $194(90.2 \%)$ \\
\hline African American & $13(6.0 \%)$ \\
\hline Hispanic & $3(1.4 \%)$ \\
\hline Other & $5 \quad(2.3 \%)$ \\
\hline Mean Body Mass Index (range) & $26.9(16.4-60.1)$ \\
\hline \multicolumn{2}{|l|}{ Procedure } \\
\hline $\begin{array}{l}\text { Open distal pancreatectomy and } \\
\text { splenectomy }\end{array}$ & $180(83.7 \%)$ \\
\hline $\begin{array}{l}\text { Open distal pancreatectomy (spleen } \\
\text { preserving) }\end{array}$ & $20(9.3 \%)$ \\
\hline $\begin{array}{l}\text { Laparoscopic distal pancreatectomy } \\
\text { and splenectomy }\end{array}$ & $9(4.2 \%)$ \\
\hline $\begin{array}{l}\text { Laparoscopic distal pancreatectomy } \\
\text { (spleen preserving) }\end{array}$ & $4(1.9 \%)$ \\
\hline Open subtotal pancreatectomy & $2(0.9 \%)$ \\
\hline Patients with additional organs resected & $108(50.2 \%)$ \\
\hline Mean operative time in minutes (range) & $274(83-665)$ \\
\hline Mean blood loss in milliliters (range) & $621(0-5400)$ \\
\hline $\begin{array}{l}\text { Median length of post-operative hospital } \\
\text { stay in days (range) }\end{array}$ & $6(2-61)$ \\
\hline
\end{tabular}


Table 3. Additional operative procedures performed.

\section{Additional Operative Procedures*}

Cholecystectomy
Gastrectomy
Partial colectomy
Wedge resection of liver
Nephrectomy
Adrenalectomy
Small bowel resection
Hysterectomy and bilateral salpingo-oophorectomy
Oophorectomy
Resection of omental mass
Orthotopic liver transplant
Pancreaticojejunostomy
Resection of retroperitoneal mass
*Some patients had more than one additional procedure

No. (\%) of Patients

$\begin{aligned} 66 & (30.1) \\ 22 & (10.2) \\ 10 & (4.7) \\ 8 & (3.7) \\ 8 & (3.7) \\ 6 & (2.8) \\ 3 & (1.4) \\ 2 & (0.9) \\ 1 & (0.5) \\ 1 & (0.5) \\ 1 & (0.5) \\ 1 & (0.5) \\ 1 & (0.5)\end{aligned}$


Table 4. Characteristics of patients with pancreatic fistula.

\section{Clinical Characteristics of Patients with Pancreatic Fistula $(n=36)$}

\begin{tabular}{|c|c|}
\hline Mean age years (range) & $53.8(21-77)$ \\
\hline \multicolumn{2}{|l|}{ Gender } \\
\hline Female & $20(55.6 \%)$ \\
\hline Male & $16(44.4 \%)$ \\
\hline Mean Body Mass Index (range) & $26.5(17.9-43)$ \\
\hline \multicolumn{2}{|l|}{ Procedure } \\
\hline $\begin{array}{l}\text { Open distal pancreatectomy and } \\
\text { splenectomy }\end{array}$ & $28(77.8 \%)$ \\
\hline $\begin{array}{l}\text { Open distal pancreatectomy (spleen } \\
\text { preserving) }\end{array}$ & $2(5.6 \%)$ \\
\hline $\begin{array}{l}\text { Laparoscopic distal pancreatectomy } \\
\text { and splenectomy }\end{array}$ & $4(11.1 \%)$ \\
\hline $\begin{array}{l}\text { Laparoscopic distal pancreatectomy } \\
\text { (spleen preserving) }\end{array}$ & $2(5.6 \%)$ \\
\hline Additional organs resected & $14(39 \%)$ \\
\hline $\begin{array}{l}\text { Median length of post-operative } \\
\text { hospital stay days (range) }\end{array}$ & $10(4-61)$ \\
\hline \multicolumn{2}{|l|}{ Grade of Fistula } \\
\hline Grade A & $16(44.4 \%)$ \\
\hline Grade B & $16(44.4 \%)$ \\
\hline Grade C & $4(11.1 \%)$ \\
\hline \multicolumn{2}{|l|}{ Management of Fistula } \\
\hline JP drain alone & $15(41.7 \%)$ \\
\hline JP drain + octreotide & $11(30.6 \%)$ \\
\hline Interventional radiology drainage & $8(22.2 \%)$ \\
\hline Endoscopic cystgastrostomy & $1(2.8 \%)$ \\
\hline Re-operation & $3(8.3 \%)$ \\
\hline
\end{tabular}


Table 5. Post-operative complications.

\section{All Post-operative Complications}

(Total patients $=215$ )

Pancreatic fistula

Intra-abdominal abscess

Small bowel obstruction

Respiratory

Cardiac

Sepsis

Wound Infection

Delayed gastric emptying

Mortality

Patients with complication

Patients without complication
\# of patients (\%)

$36(16.7)$

$22(10.2)$

8 (3.7)

$6(2.8)$

$5(2.3)$

$4(1.9)$

$3(1.4)$

$2(0.9)$

$2(0.9)$

$55(25.6)$

$160(74.4)$ 
Table 6. Bivariate Analysis

Bivariate Analysis: Proportion of cases with pancreatic fistula by selected risk factors

$\begin{array}{cccc}\begin{array}{c}\text { Method of pancreatic } \\ \text { transection }\end{array} & \begin{array}{c}\text { Not stapled } \\ 4 / 73=5.48 \%\end{array} & \begin{array}{c}\text { Stapled } \\ 31 / 139=22.30 \%\end{array} & \begin{array}{c}\text { Chi-square=9.83, } \mathrm{df}=1, \\ \mathrm{p}=0.002\end{array} \\ \begin{array}{c}\text { Method of sealing } \\ \text { pancreatic remnant }\end{array} & \text { Oversewn } & \text { Not oversewn } & \begin{array}{c}\text { Chi-square }=6.30, \mathrm{df}=1, \\ \mathrm{p}=0.012\end{array} \\ & 21 / 161=13.04 \% & 15 / 54=27.78 \% & \\ \text { Surgeon volume } & \text { High } & \text { Low } & \begin{array}{c}\text { Chi-square }=11.05, \mathrm{df}=1, \\ \mathrm{p}<.001\end{array}\end{array}$


Table 7. Multivariate Logistic Regression Analysis

\section{Multivariate Logistic Regression Analysis}

\begin{tabular}{|c|c|c|c|c|c|c|c|}
\hline Variable & Effect & $\begin{array}{l}\text { Odds } \\
\text { Ratio }\end{array}$ & $\begin{array}{l}95 \% \\
\text { LCL }\end{array}$ & $\begin{array}{l}95 \% \\
\text { UCL }\end{array}$ & df & $\begin{array}{l}\text { Wald } \\
\text { X2 }\end{array}$ & $p$-value \\
\hline \multirow{3}{*}{ Age } & $50-59$ vs. $18-49$ & 0.565 & 0.188 & 1.696 & \multirow{3}{*}{3} & \multirow{3}{*}{2.0570} & \multirow{3}{*}{0.5607} \\
\hline & $60-69$ vs. $18-49$ & 0.524 & 0.175 & 1.564 & & & \\
\hline & $70+$ vs. $18-49$ & 0.521 & 0.174 & 1.563 & & & \\
\hline Gender & Male vs. Female & 1.137 & 0.485 & 2.666 & 1 & 0.0870 & 0.7680 \\
\hline Body Mass Index & $\begin{array}{c}25-29.99 \text { vs. }<25 \\
>=30 \text { vs. }<25\end{array}$ & $\begin{array}{l}1.238 \\
0.658\end{array}$ & $\begin{array}{l}0.498 \\
0.237\end{array}$ & $\begin{array}{l}3.081 \\
1.825\end{array}$ & 2 & 1.3065 & 0.5203 \\
\hline \multirow{2}{*}{$\begin{array}{c}\text { Estimated Blood } \\
\text { Loss }\end{array}$} & $200-499$ vs. $<200$ & 2.023 & 0.684 & 5.981 & \multirow{2}{*}{3} & \multirow{2}{*}{1.7330} & \multirow[b]{2}{*}{0.6296} \\
\hline & $\begin{array}{c}500-/ 99 \text { vs. }<200 \\
800+v s<200\end{array}$ & $\begin{array}{l}1.744 \\
1.407\end{array}$ & $\begin{array}{l}0.440 \\
0.395\end{array}$ & $\begin{array}{l}6.903 \\
5.014\end{array}$ & & & \\
\hline $\begin{array}{l}\text { Method of } \\
\text { pancreatic } \\
\text { transection }\end{array}$ & $\begin{array}{l}\text { Stapled vs. Non- } \\
\text { stapled }\end{array}$ & 3.242 & 0.962 & 10.928 & 1 & 3.5980 & 0.0578 \\
\hline $\begin{array}{l}\text { Method of sealing } \\
\text { pancreatic remnant }\end{array}$ & $\begin{array}{c}\text { Not oversewn vs. } \\
\text { Oversewn }\end{array}$ & 1.570 & 0.669 & 3.686 & 1 & 1.0744 & 0.2999 \\
\hline Surgeon volume & Low vs. High & 1.881 & 0.785 & 4.510 & 1 & 2.0066 & 0.1566 \\
\hline
\end{tabular}


Figure 1.

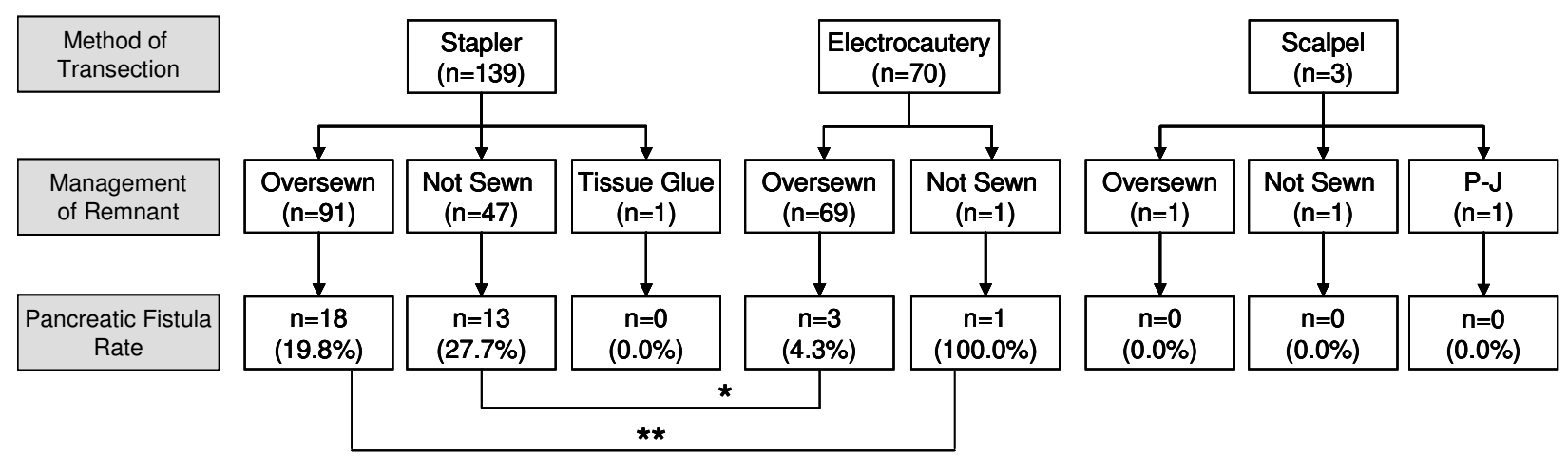

P-J=pancreaticojejunostomy, ${ }^{*} \mathrm{p}=0.0006,{ }^{* *} \mathrm{p}=0.004$

Figure 1 Legend-Flowsheet demonstrating the breakdown of patients by method of transection of pancreatic remnant, management of the remnant, and fistula rates.

Figure 2.

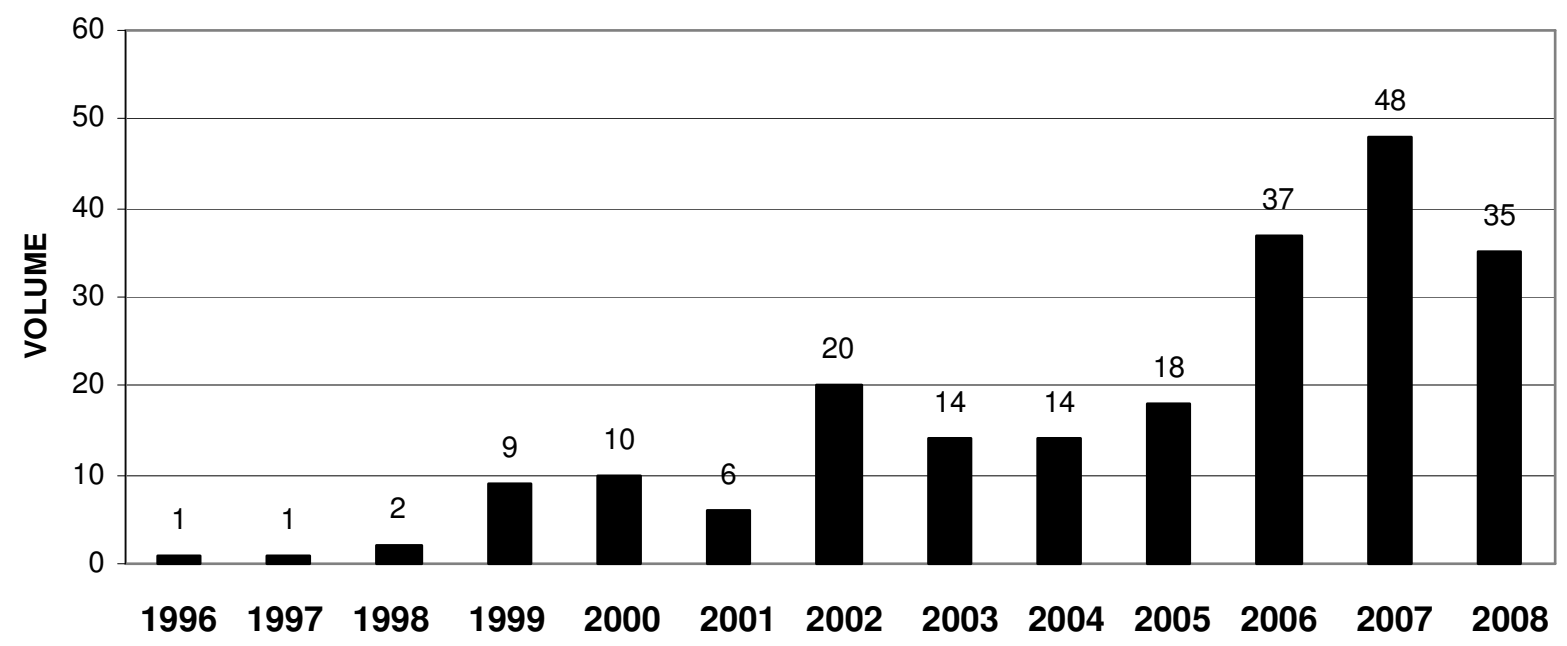

Graph demonstrating increasing volume of distal pancreatectomies by year at Thomas Jefferson University Hospital. 